\title{
Chemical Synthesis and Orexigenic Activity of Rat/Mouse Relaxin-3
}

Mohammed Akhter Hossain ${ }^{* 1-3}$, Craig M. Smith ${ }^{1,4}$, Philip J. Ryan ${ }^{1,4}$, Elena Büchler ${ }^{1, \dagger}$, Ross A.D. Bathgate ${ }^{1,2,5}$, Andrew L. Gundlach ${ }^{1,2,4}$ and John D. Wade ${ }^{* 1-3}$

${ }^{1}$ The Florey Institute of Neuroscience and Mental Health, ${ }^{2}$ Florey Department of Neuroscience and Mental Health, ${ }^{3}$ School of Chemistry, ${ }^{4}$ Department of Anatomy and Neuroscience and ${ }^{5}$ Department of Biochemistry and Molecular Biology, The University of Melbourne, Victoria 3010, Australia

†Current Address: Department of Psychopharmacology, Central Institute of Mental Health, Mannheim, Germany

Address correspondence to:

Dr Mohammed Akhter Hossain, Tel: +61 383447330

Email: akhter.hossain@unimelb.edu.au

Prof John D. Wade, Tel: +61 383447330

Email: john.wade@florey.edu.au 


\begin{abstract}
The insulin-like peptide, relaxin-3, was first identified just a decade ago via a genomic database search and is now recognized to be a key neuropeptide with several roles including the regulation of arousal, stress responses and neuroendocrine homeostasis. It also has significant potential as a drug to treat stress and obesity. Its actions are mediated via its cognate $\mathrm{G}$ protein-coupled receptor, RXFP3, which is found in abundant numbers in the brain. However, much remains to be determined with respect to the mechanism of neurological action of this peptide. Consequently, the chemical synthesis of the rat and mouse (which share identical primary structures) two-chain, three disulfide peptide was undertaken and the resulting peptide subjected to detailed in vitro and in vivo assay. Use of efficient solid phase synthesis methods provided the two regioselectively S-protected A- and B-chains which were efficiently combined via sequential disulfide bond formation. The synthetic rat/mouse relaxin-3 was obtained in high purity and good overall yield. It demonstrated potent orexigenic activity in rats in that central intracerebroventricular infusion led to significantly increased food intake and water drinking.
\end{abstract}

\title{
KEYWORDS
}

Solid phase peptide synthesis, relaxin-3, RXFP3, Insulin-like peptide 7, rat/mouse relaxin-3 


\section{INTRODUCTION}

Relaxin-3 is a highly conserved 51 amino acid neuropeptide that was discovered in 2002 (Bathgate et al. 2002; Burazin et al. 2002; Wilkinson et al. 2005; Bathgate et al. 2005). It primarily binds to and activates the Gprotein-coupled receptor, Relaxin Family Peptide 3 receptor (RXFP3) in vivo (Liu et al. 2003), although it can also bind to and activate the related receptors, RXFP1 and RXFP4, both in vitro and in vivo but with lower affinity (Sudo et al. 2003; Bathgate et al. 2005; Bathgate et al. 2006b). Relaxin-3 and RXFP3 are highly expressed in the brain and studies that have mapped their neuroanatomical distribution within rat (Burazin et al. 2002; Tanaka et al. 2005; Ma et al. 2007) and mouse (Smith et al. 2010) brain have indicated that the relaxin3/RXFP3 system likely modulates a number of key limbic, hypothalamic, and broadly distributed neuronal circuits that control modalities such as arousal, stress responses, and metabolic and neuroendocrine homeostasis (Smith et al. 2011; Gundlach et al. 2013).

Indeed, since its discovery the role of the relaxin-3/RXFP3 system in the brain has been investigated in a number of in vivo studies and examinations of physiology and behaviour following central infusion of $\mathrm{H} 3$ relaxin or mimetic peptides have been particularly informative in indicating the endogenous functions of relaxin-3, although these studies have to date been exclusively conducted in rats. Most notably, acute intracerebroventricular (icv) infusion of human relaxin-3 (H3 relaxin) was shown to increase food consumption during the hour post-infusion (McGowan et al. 2005). Since this initial finding, several independent studies have confirmed that acute central infusion of H3 relaxin or specific RXFP3 agonist peptides are potently orexigenic in rats, while chronic infusion results in bodyweight gain and associated metabolic effects (McGowan et al. 2007; McGowan et al. 2006; Hida et al. 2006; Sutton et al. 2009; Ganella et al. 2012a; Ganella et al. 2012b). Other effects of central icv or local infusion of $\mathrm{H} 3$ relaxin or specific RXFP3 agonists have been noted, such as stimulation of the hypothalamic-pituitary-adrenal (HPA) and hypothalamic-adrenal-gonadal (HPG) axes (McGowan et al. 2008; Watanabe et al. 2010), and modulation of hippocampal theta rhythm (Ma et al. 2009).

Human relaxin-2 (known as 'relaxin' in non-human species) is another member of the relaxin family of peptides and its cognate receptor is RXFP1(Bathgate et al. 2006b). Relaxin is a hormone long studied for its roles in peripheral tissues, especially during pregnancy (Hisaw 1926; Sherwood 2004); but relaxin also signals within the brain, and stimulates water drinking in rats, via strong RXFP1 activation within the circumventricular organs and hypothalamic brain regions that control fluid balance (Hornsby et al. 2001; Sunn et al. 2002). H3 Relaxin infusion has been reported to increase water consumption to a level comparable to that mediated by $\mathrm{H} 2$ relaxin (Bathgate et al. 2006b; McGowan et al. 2005), but as H3 relaxin can bind/activate RXFP1, the dipsogenic response produced by $\mathrm{H} 3$ relaxin is likely to be primarily due to activation of RXFP1 rather than RXFP3. This idea is supported by a recent study in which central infusion of H3 relaxin activated neurons within circumventricular organs and fluid balance-related regions in a pattern almost identical to that elicited by H2 relaxin (Otsubo et al. 2010). RXFP1 is also expressed by neurons within deeper brain tissues and circuits of rat brain (Ma et al. 2006)suggesting it can affect a range of complex behaviours, although few studies have investigated this possibility directly, apart from an early report on the effect of RXFP1 activation within the amygdala on aversive memory consolidation (Ma et al. 2005).

With the aim of facilitating future pharmacological studies in rodents to further probe the function of relaxin-3, here we describe the novel synthesis of rat/mouse relaxin-3 (i.e. the sequence of relaxin-3 is identical in both species) (Wilkinson et al. 2005; Bathgate et al. 2006a). Although rat/mouse relaxin-3 only differs from 
H3 relaxin by four amino acids, the injection into rats or mice of 'native' peptide, rather than a foreign peptide species, is favoured where possible to eliminate the potential of an immune response and to minimize 'nonendogenous' cross-reactive receptor binding. Therefore, the present studies describe the efficient chemical synthesis, structural analysis and detailed in vitro and in vivo biological activity of rat/mouse relaxin-3.

\section{MATERIALS AND METHODS}

\section{Materials}

9-Fluorenylmethoxycarbonyl (Fmoc) protected L- $\alpha$-amino acids and 1-[bis(dimethylamino)methylene]-1Hbenzotriazolium hexafluorophosphate 3-oxide (HBTU) were purchased from GL Biochem (Shanghai, China). Piperidine (PPD) and trifluoroacetic acid (TFA) were purchased from Auspep (Melbourne, Australia). FmocPAL-PEG-PS resins with substitution of $0.18 \mathrm{mmol} / \mathrm{g}$ were purchased from Applied Biosystems Inc. (Melbourne, Australia). Dimethylformamide (DMF), methanol, diethyl ether, and dichloromethane (DCM) were purchased from Merck (Melbourne, Australia). 3,6-Dioxa-1,8-octanedithiol (DODT), triisopropylsilane (TIPS), diisopropylethylamine (DIPEA) and trifluoromethanesulfonic acid (TFMSA) were purchased from SigmaAldrich (Sydney, Australia). 2,2-Dipyridyl disulfide (DPDS) was purchased from Fluka (Switzerland). Acetonitrile was purchased from BDH Laboratory Supplies, (Poole, UK). All other reagents were from SigmaAldrich (Sydney, Australia).

\section{Methods}

\section{Solid-phase peptide synthesis}

For rat/mouse and human relaxin-3, regioselectively S-protected A- and B-chains were separately synthesized by the continuous flow Fmoc solid-phase method using an automatic PerSeptive Biosystems Pioneer peptide synthesizer (Framingham, MA, USA) or by using microwave-assisted synthesis on a Liberty system (CEM Corporation, Charlotte, NC, USA) (Wade et al. 2012). The synthetic A- and B-chains were then subjected to sequential disulfide bond formation as previously described (Hossain et al. 2008).

\section{Peptide characterization}

The purity of the synthetic peptides was assessed by analytical RP-HPLC on a Phenomenex C18 column (pore size $300 \AA$, particle size $5 \mu \mathrm{m}, 4.6 \times 250 \mathrm{~mm}$ ) using a gradient of acetonitrile in $0.1 \%$ aqueous trifluoroacetic acid. The product was confirmed by MALDI-TOF mass spectrometry using a Bruker Autoflex II instrument (Bremen, Germany) in the linear mode at $19.5 \mathrm{kV}$. The peptides were quantified by amino acid analysis of a 24 $\mathrm{h}$ acid hydrolysate using a Shimadzu microbore RP-HPLC system.

\section{Circular dichroism (CD) spectra}

CD spectra were recorded between 200 and $250 \mathrm{~nm}$ on JASCO (J-185, Tokyo, Japan) at $25^{\circ} \mathrm{C}$ using $1 \mathrm{~mm}$ path length cell. The peptide was dissolved in $10 \mathrm{mM}$ phosphate buffer with $137 \mathrm{mM} \mathrm{NaCl}(\mathrm{pH} \mathrm{7.4)}$ at a concentration of $0.1 \mathrm{mg} / \mathrm{ml}$. 
CHO-K1 cells stably expressing RXFP3 were plated into a 96 well plate (Viewplate; opaque white wall and clear bottom, PerkinElmer, Glen Waverly, Australia) at a density of $5 \times 10^{4}$ cells/well and grown over night to reach $\sim 90 \%$ confluence before experimentation. Binding assays were conducted as described (Shabanpoor et al. 2011)Briefly, the competition binding assay was conducted using a single concentration of Eu-labelled INSL5A/H3 relaxin B (Eu-R3/I5) $(0.5 \mathrm{nM})$ in the presence of increasing concentrations of rat/mouse relaxin-3. The binding affinity of rat/mouse relaxin-3 was compared with synthetic H3 relaxin. Each concentration point was performed in triplicate and the data expressed as the mean \pm SEM of three independent experiments.

\section{Inhibition of forskolin induced cAMP accumulation}

The potency of the synthetic rat/mouse relaxin-3 and $\mathrm{H} 3$ relaxin was assessed by measuring their influence on forskolin-induced cAMP signalling in CHO-K1 cells stably expressing RXFP3 as previously reported (Shabanpoor et al. 2012).

\section{Animals}

Male Sprague-Dawley rats $(n=15 ; 250-300 \mathrm{~g})$, supplied by the Animal Resources Centre (Perth, Australia) were housed under ambient conditions $\left(21^{\circ} \mathrm{C}\right)$ and maintained on a 12h light:dark cycle (lights on 0700-1900) with access to laboratory chow and water ad libitum. Experiments were conducted with the approval of the Florey Institute Animal Welfare Committee and according to the ethical guidelines issued by the National Health and Medical Research Council of Australia.

\section{Stereotaxic implantation of cannula into lateral ventricle}

Rats were deeply anaesthetised with $4 \%$ isoflurane in oxygen, 2 1/min (Delvet, Seven Hills, Australia), and maintained with 2-3\% isoflurane in oxygen, $0.2 \mathrm{~L} / \mathrm{min}$. Each rat was positioned in a stereotaxic frame (David Kopf Instruments, Tujunga, USA) and a stainless-steel guide cannula (22 gauge, cut $5 \mathrm{~mm}$ below pedestal; Plastics One, Roanoke, USA) was implanted with the cannula tip inserted into the lateral ventricle (coordinates: anteroposterior, $-0.8 \mathrm{~mm}$; mediolateral, $-1.5 \mathrm{~mm}$; dorsolateral $-3.5 \mathrm{~mm}$ ) (Paxinos and Watson 2007) and affixed to the skull using surgical screws and dental cement. Rats were then placed under a heat lamp in a clean cage until regaining consciousness. Meloxicam ( $3 \mathrm{mg} / \mathrm{kg}$, i.p.; Troy Laboratories, Smithfield, Australia) and 0.5 $\mathrm{mg} / \mathrm{ml}$ paracetamol in $5 \%$ sucrose/water (for 3 days) were administered to provide acute and ongoing postoperative analgesia, respectively. Baytril 50 (enrofloxacin) $(2 \mathrm{mg} / \mathrm{kg}$, i.p; Bayer Australia Ltd, Pymble, Australia) was administered post-operatively as a prophylactic antibiotic.

Rats were single-housed and allowed to recover for 7 days, during which time they were handled and weighed daily to habituate them to the experimenter. A stylet of stainless steel wire (30-gauge) was inserted into each cannula that extended no further than the base of the cannula to maintain patency.

\section{Infusion procedure and verification of cannulation using angiotensin II}

Lateral ventricle infusions were made using 29-gauge hypodermic tubing (Small Parts Inc., Miramar, USA) connected to a $10 \mu$ Hamilton microsyringe (Hamilton Instruments, Reno, USA) by polyethylene tubing $(0.80$ $\mathrm{mm}$ outer and $0.40 \mathrm{~mm}$ internal diameter; Microtube Extrusions, North Rocks, Australia). Correct positioning of the cannula was verified in each rat by injecting $5 \mu \mathrm{l}$ of a $4 \mathrm{ng} / \mu \mathrm{l}$ solution of human angiotensin II (Auspep, 
Parkville, Australia) in artificial cerebrospinal fluid (aCSF; $147 \mathrm{mM} \mathrm{NaCl} ; 4 \mathrm{mM} \mathrm{KCl} ; 0.85 \mathrm{mM} \mathrm{MgCl} 2 ; 2.3$ $\mathrm{mM} \mathrm{CaCl}_{2}$ ), and observing if this produced a positive dipsogenic response, defined as repeated drinking episodes of $\geq 5 \mathrm{sec}$ that commenced within $1 \mathrm{~min}$ of angiotensin II administration. Injectors that extended 1.5 or $2 \mathrm{~mm}$ below the base of the cannula were tested as required on consecutive days and the length of the effective injector was recorded for each rat and used for all subsequent experiments. Rats that failed to display a drinking response were used as controls in subsequent experiments.

\section{Peptide treatment}

Rat/mouse relaxin-3 was dissolved in aCSF vehicle at a concentration of $2 \mu \mathrm{g} / \mu \mathrm{l}$. Rats were divided into two groups - group 1 received a $5 \mu \mathrm{l}$ injection of rat/mouse relaxin-3 (equivalent to $10 \mu \mathrm{g}$ ); group 2 received $5 \mu \mathrm{l}$ of aCSF (vehicle).

\section{Food and water intake}

Rats were habituated for a minimum of 7 days to the holding room and behavioural studies were performed during the light phase, beginning at $1100 \mathrm{~h}$. Groups of rats were injected as described. Following infusion, rats were returned to their home cage where a pre-weighed amount of rat chow (10-13 g) was located in the food compartment of the wire cage lid. A pre-weighed water bottle was also placed in its usual compartment, and food and water were then weighed $1 \mathrm{~h}$ post-infusion.

\section{Data analysis}

Data were analysed using GraphPad Prism V5.00 for Windows (GraphPad Software, San Diego, USA). Results are expressed as mean \pm SEM. Statistical significance was evaluated using a Student's t-test with $\mathrm{P}<0.05$ considered significant. Food and water intake levels of rats that were 'mock injected' were combined with data from the vehicle injected group, as there was no significant difference between them.

\section{RESULTS AND DISCUSSION}

Definitive physiological roles of $\mathrm{H} 3$ relaxin in human are not yet known, but anatomical, neurochemical and pharmacological studies in rodents have identified the extensive brain relaxin-3/RXFP3 signalling networks as potential targets for the treatment of a range of psychiatric conditions, including anxiety, depression, sleep disorders, and associated cognitive deficits (Smith et al. 2011). Over recent years, in vivo pharmacological studies to explore the function of the relaxin-3/RXFP3 system have been greatly facilitated by the development of several synthetic RXFP3 agonist and antagonist peptides (Shabanpoor et al. 2012; Haugaard-Kedstrom et al. 2011; Kuei et al. 2007; Liu et al. 2005)[32, 34-36]. In line with these endeavours, the present studies describe the synthesis of rat/mouse relaxin-3, which represents an important addition to the pharmacological tool box available to investigate relaxin-3/RXFP3 systems in the major experimental species of rodents.

\section{Chemical assembly of rat/mouse relaxin-3}

A regioselective disulfide synthesis approach was used to synthesize rat/mouse relaxin-3. Three differential cysteine S-protecting groups (Trt, $\mathrm{tBu}$ and $\mathrm{Acm}$ ) were used that allowed the directed formation of three disulfide bonds. Solid phase synthesis of the separate, selectively S-protected A- and B-chains followed by their 
purification and subsequent stepwise formation of each of the three disulfides via oxidation, thioloysis, and iodolysis (Hossain et al. 2008; Hossain et al. 2009; Hossain et al. 2010) led to the successful preparation of rat/mouse relaxin-3. Its analytical RP-HPLC profile (Fig. 1A) and MALDI TOF MS spectrometry (theoretical, MH+ 5497.51; found, MH+ 5497.87; Fig. 1B) revealed a highly purified synthetic product. The peptide content (81.6\%) and amino acid composition were determined by amino acid analysis. Rat/mouse relaxin-3 was made as the $\mathrm{C}$-termini amide and the yield ( 12\%) was comparable to $\mathrm{H} 3$ relaxin amide (11\%), and was twice that of $\mathrm{H} 3$ acid ( 6\%) (Bathgate et al. 2006b). We also synthesized H3 relaxin for comparative purposes.

\section{Conformation of rat/mouse relaxin-3}

The conformation of synthetic rat/mouse relaxin-3 was analyzed by CD spectroscopy (Fig. 2). H3 relaxin was used as a control due to its sequence similarity with rat/mouse relaxin-3, and because it has been well characterized (Bathgate et al. 2006b). Both human and rat/mouse relaxin-3 form a significant degree of helical conformation. The helix content of rat/mouse relaxin-3, calculated from the mean residual weight ellipticity at $222 \mathrm{~nm},[\theta]_{222}$ (Scholtz et al. 1991), was overlapping with H3 relaxin (32\%), indicating that rat/mouse relaxin-3 has the same or similar secondary structure to $\mathrm{H} 3$ relaxin, which does not appear to be affected by the four amino acid differences between the two peptides.

\section{Activity of rat/mouse relaxin-3 at RXFP3}

Synthetic rat/mouse relaxin-3 was first tested for its ability to bind human RXFP3 (Fig. 3A), and it demonstrated slightly higher affinity at RXFP3 than H3 relaxin, although the difference was not statistically significant. Rat/mouse relaxin-3 was then tested for its ability to inhibit forskolin induced cAMP production in human RXFP3 transfected CHO cells, as RXFP3 is $\mathrm{G}_{\mathrm{i} / 0}$-coupled and its activation has been shown to inhibit cAMP (Liu et al. 2003). Rat/mouse relaxin-3 was able to decrease forskolin induced cAMP activity in a dosedependent manner and to a similar degree as $\mathrm{H} 3$ relaxin (Fig. 3B). These findings demonstrate that rat/mouse relaxin-3 is a high affinity, potent ligand for human RXFP3 in vitro, with properties indistinguishable from $\mathrm{H} 3$ relaxin.

\section{Central infusion of rat/mouse relaxin-3 in rats}

Several studies have demonstrated that central infusion of H3 relaxin or RXFP3-selective agonist peptides in rats is potently orexigenic (see Introduction), and that this effect is mediated via RXFP3, as pre-administration of an RXFP3 antagonist blocks the increase in food intake (Haugaard-Kedstrom et al. 2011), and H2 relaxin decreases food intake following local injection into the hypothalamus (McGowan et al. 2010). Furthermore, central infusion of $\mathrm{H} 3$ relaxin (but not selective RXFP3 agonists) in rats increases water drinking via RXFP1 activation (Bathgate et al. 2006b; McGowan et al. 2005; Otsubo et al. 2010). Therefore, to test the ability of rat/mouse relaxin-3 to activate RXFP3 and RXFP1 in vivo, food and water consumption following acute icv infusion of rat/mouse relaxin-3 (10 $\mu \mathrm{g}, \sim 2 \mathrm{nmol})$ was assessed in rats.

During the hour post infusion, rats injected with rat/mouse relaxin-3 consumed significantly more food than control rats (Fig. 4A; p < 0.05), and also drank more water (Fig. 4B; $<<0.05$ ), consistent with biological activity of rat/mouse relaxin-3 at RXFP3 and RXFP1. Rats were used rather than mice for several reasons. Firstly, the behavioural response of rats to icv infusion of $\mathrm{H} 3$ relaxin or RXFP3 selective agonists is known to 
be robust and reproducible, whereas the equivalent response in mice is not yet well characterized, and secondly, although $\mathrm{H} 3$ relaxin (and rat/mouse relaxin-3) can pharmacologically bind/activate RXFP4 in vitro (Liu et al. 2005; Bathgate et al. 2013), RXFP4 is a pseudogene in rats (Chen et al. 2005) and hence cannot contribute to any effects of relaxin-3 observed in vivo. However, as RXFP4 expression is absent or very low (undetectable) in mouse brain (Sutton et al. 2009), rat/mouse relaxin-3 could be used in future studies of native relaxin-3 effects in mouse brain, relative to the effects of RXFP3 selective peptides.

\section{Conclusion}

These studies describe the first chemical preparation of rat/mouse relaxin-3. In vitro testing of the peptide revealed correct secondary structure conformation and potent RXFP3 binding activity, while icv infusion in rats increased food intake and water drinking, consistent with predicted biological activity at both relaxin-3 and relaxin receptors, RXFP3 and RXFP1, respectively. Synthetic rat/mouse relaxin-3 thus provides a valuable complement to $\mathrm{H} 3$ relaxin for future in vivo pharmacological studies in rats or mice. Such approaches are powerful for probing the endogenous role of relaxin-3 in the brain under different physiological and pathological conditions, particularly in combination with the use of relevant transgenic mouse models and complementary viral-based methods (Ganella et al. 2012a; Smith et al. 2012). Current efforts are focusing on the preparation of stable analogues of relaxin-3(Werle and Bernkop-Schnurch 2010) with the goal of delivering it via iv or ip routes, possibly with the aid of brain targeting adducts ( $\mathrm{Li}$ et al. 2012). Such studies are an important scientific and translational endeavour, as the relaxin-3/RXFP3 system represents a promising target for the development of treatments for a variety of metabolic, neuroendocrine and psychiatric diseases.

\section{Acknowledgements}

This research was funded by NHMRC (Australia) project grants 508995, and 1023078 to JDW, MAH and RADB and 1005988 to ALG and RADB. We are grateful to Tania Ferraro and Sharon Layfield for assistance with biochemical assays and to Feng Lin for amino acid analysis. MAH was the recipient of a Florey Foundation Fellowship and RADB, ALG and JDW are NHMRC (Australia) Research Fellows. Research at the Florey Institute of Neuroscience and Mental Health is supported by the Victorian Government Operational Infrastructure Support Program. 


\section{References}

Bathgate R, Samuel C, Burazin T, Layfield S, Claasz A, Reytomas I, Dawson N, Zhao C, Bond C, Summers R, Parry L, Wade J (2002) Human relaxin gene 3 (H3) and the equivalent mouse relaxin (M3) gene: Novel members of the relaxin peptide family. Journal of Biological Chemistry 277:1148-1157

Bathgate RA, Ivell R, Sanborn BM, Sherwood OD, Summers RJ (2005) Receptors for relaxin family peptides. Ann N Y Acad Sci 1041:61-76

Bathgate RAD, Halls ML, van der Westhuizen ET, Callander GE, Kocan M, Summers RJ (2013) Relaxin family peptides and their receptors. Physiol Rev 93:405-480

Bathgate RAD, Ivell R, Sanborn BM, Sherwood OD, Summers RJ (2006a) International Union of Pharmacology LVII: recommendations for the nomenclature of receptors for relaxin family peptides. Pharmacol Rev 58:7-31

Bathgate RAD, Lin F, Hanson NF, Otvos L, Jr., Guidolin A, Giannakis C, Bastiras S, Layfield SL, Ferraro T, Ma S, Zhao C, Gundlach AL, Samuel CS, Tregear GW, Wade JD (2006b) Relaxin-3: improved synthesis strategy and demonstration of its high-affinity interaction with the relaxin receptor LGR7 both in vitro and in vivo. Biochemistry 45:1043-1053

Burazin TCD, Bathgate RAD, Macris M, Layfield S, Gundlach AL, Tregear GW (2002) Restricted, but abundant, expression of the novel rat gene-3 (R3) relaxin in the dorsal tegmental region of brain. J Neurochem 82:1553-1557

Chen J, Kuei C, Sutton SW, Bonaventure P, Nepomuceno D, Eriste E, Sillard R, Lovenberg TW, Liu C (2005) Pharmacological characterization of relaxin-3/INSL7 receptors GPCR135 and GPCR142 from different mammalian species. J Pharmacol Exp Ther 312:83-95

Ganella DE, Callander GE, Ma S, Bye CR, Gundlach AL, Bathgate RA (2012a) Modulation of feeding by chronic rAAV expression of a relaxin-3 peptide agonist in rat hypothalamus. Gene Ther doi: $10.1038 /$ gt. 2012.83

Ganella DE, Ryan PJ, Bathgate RA, Gundlach AL (2012b) Increased feeding and body weight gain in rats after acute and chronic activation of RXFP3 by relaxin-3 and receptor-selective peptides: functional and therapeutic implications. Behav Pharmacol 23:516-525

Gundlach AL, Smith CM, Ryan PJ, Blasiak A, Olucha-Bordonau FE, Ma S (2013) Relaxin-3 and related relaxin family peptide systems in brain. In:. The Handbook of Biologically Active Peptides, Second Edition, Kastin, A., Ed., Elsevier, San Diego

Haugaard-Kedstrom LM, Shabanpoor F, Hossain MA, Clark RJ, Ryan PJ, Craik DJ, Gundlach AL, Wade JD, Bathgate RA, Rosengren KJ (2011) Design, synthesis, and characterization of a single-chain peptide antagonist for the relaxin-3 receptor RXFP3. J Am Chem Soc 133:4965-4974

Hida T, Takahashi E, Shikata K, Hirohashi T, Sawai T, Seiki T, Tanaka H, Kawai T, Ito O, Arai T, Yokoi A, Hirakawa T, Ogura H, Nagasu T, Miyamoto N, Kuromitsu J (2006) Chronic intracerebroventricular administration of relaxin-3 increases body weight in rats. J Recept Signal Transduct Res 26:147-158

Hisaw F (1926) Experimental relaxation of the pubic ligament of the guinea pig. Proc Soc Exp Biol Med 23:661 $-663$

Hornsby DJ, Wilson BC, Summerlee AJ (2001) Relaxin and drinking in pregnant rats. Prog Brain Res 133:229240 
Hossain MA, Bathgate RA, Rosengren KJ, Shabanpoor F, Zhang S, Lin F, Tregear GW, Wade JD (2009) The structural and functional role of the B-chain C-terminal arginine in the relaxin-3 peptide antagonist, R3(BDelta23-27)R/I5. Chem Biol Drug Des 73:46-52

Hossain MA, Rosengren KJ, Haugaard-Jonsson LM, Zhang S, Layfield S, Ferraro T, Daly NL, Tregear GW, Wade JD, Bathgate RA (2008) The A-chain of human relaxin family peptides has distinct roles in the binding and activation of the different relaxin family peptide receptors. J Biol Chem 283:17287-17297

Hossain MA, Samuel CS, Binder C, Hewitson TD, Tregear GW, Wade JD, Bathgate RA (2010) The chemically synthesized human relaxin-2 analog, B-R13/17K H2, is an RXFP1 antagonist. Amino Acids 39:409-416

Kuei C, Sutton S, Bonaventure P, Pudiak C, Shelton J, Zhu J, Nepomuceno D, Wu J, Chen J, Kamme F, Seierstad M, Hack MD, Bathgate RAD, Hossain MA, Wade JD, Atack J, Lovenberg TW, Liu C (2007) R3(BDelta23 27)R/I5 chimeric peptide, a selective antagonist for GPCR135 and GPCR142 over relaxin receptor LGR7: in vitro and in vivo characterization. J Biol Chem 282:25425-25435

Li J, Zhang Q, Pang Z, Wang Y, Liu Q, Guo L, Jiang X (2012) Identification of peptide sequences that target to the brain using in vivo phage display. Amino Acids 42:2373-2381

Liu C, Chen J, Kuei C, Sutton S, Nepomuceno D, Bonaventure P, Lovenberg TW (2005) Relaxin-3/insulin-like peptide 5 chimeric peptide, a selective ligand for G protein-coupled receptor (GPCR)135 and GPCR142 over leucine-rich repeat-containing $\mathrm{G}$ protein-coupled receptor 7. Mol Pharmacol 67:231-240

Liu C, Eriste E, Sutton S, Chen J, Roland B, Kuei C, Farmer N, Jornvall H, Sillard R, Lovenberg TW (2003) Identification of relaxin-3/INSL7 as an endogenous ligand for the orphan G-protein-coupled receptor GPCR135. J Biol Chem 278:50754-50764

Ma S, Bonaventure P, Ferraro T, Shen PJ, Burazin TCD, Bathgate RAD, Liu C, Tregear GW, Sutton SW, Gundlach AL (2007) Relaxin-3 in GABA projection neurons of nucleus incertus suggests widespread influence on forebrain circuits via G-protein-coupled receptor-135 in the rat. Neuroscience 144:165-190

Ma S, Olucha-Bordonau FE, Hossain MA, Lin F, Kuei C, Liu C, Wade JD, Sutton SW, Nunez A, Gundlach AL (2009) Modulation of hippocampal theta oscillations and spatial memory by relaxin-3 neurons of the nucleus incertus. Learn Mem 16:730-742

Ma S, Roozendaal B, Burazin TC, Tregear GW, McGaugh JL, Gundlach AL (2005) Relaxin receptor activation in the basolateral amygdala impairs memory consolidation. Eur J Neurosci 22:2117-2122

Ma S, Shen PJ, Burazin TC, Tregear GW, Gundlach AL (2006) Comparative localization of leucine-rich repeatcontaining G-protein-coupled receptor-7 (RXFP1) mRNA and [33P]-relaxin binding sites in rat brain: restricted somatic co-expression a clue to relaxin action? Neuroscience 141:329-344

McGowan BM, Minnion JS, Murphy KG, White NE, Roy D, Stanley SA, Dhillo WS, Gardiner JV, Ghatei MA, Bloom SR (2010) Central and peripheral administration of human relaxin-2 to adult male rats inhibits food intake. Diabetes Obes Metab 12:1090-1096

McGowan BM, Stanley SA, Donovan J, Thompson EL, Patterson M, Semjonous NM, Gardiner JV, Murphy K, Ghatei MA, Bloom SR (2008) Relaxin-3 stimulates the hypothalamic-pituitary-gonadal axis. Am J Physiol Endocrinol Metab 295:E278-E286

McGowan BM, Stanley SA, Smith KL, Minnion JS, Donovan J, Thompson EL, Patterson M, Connolly MM, Abbott CR, Small CJ, Gardiner JV, Ghatei MA, Bloom SR (2006) Effects of acute and chronic relaxin-3 on food intake and energy expenditure in rats. Regul Pept 136:72-77 
McGowan BM, Stanley SA, Smith KL, White NE, Connolly MM, Thompson EL, Gardiner JV, Murphy KG, Ghatei MA, Bloom SR (2005) Central relaxin-3 administration causes hyperphagia in male Wistar rats. Endocrinology 146:3295-3300

McGowan BM, Stanley SA, White NE, Spangeus A, Patterson M, Thompson EL, Smith KL, Donovan J, Gardiner JV, Ghatei MA, Bloom SR (2007) Hypothalamic mapping of orexigenic action and Fos-like immunoreactivity following relaxin-3 administration in male Wistar rats. Am J Physiol Endocrinol Metab 292:E913-919

Otsubo H, Onaka T, Suzuki H, Katoh A, Ohbuchi T, Todoroki M, Kobayashi M, Fujihara H, Yokoyama T, Matsumoto T, Ueta Y (2010) Centrally administered relaxin-3 induces Fos expression in the osmosensitive areas in rat brain and facilitates water intake. Peptides 31:1124-1130

Paxinos G, Watson C (2007) The rat brain in stereotaxic coordinates. Sixth edition, Academic press, London.

Scholtz JM, Qian H, York EJ, Stewart JM, Baldwin RL (1991) Parameters of helix-coil transition theory for alanine-based peptides of varying chain lengths in water. Biopolymers 31:1463-1470

Shabanpoor F, Akhter Hossain M, Ryan PJ, Belgi A, Layfield S, Kocan M, Zhang S, Samuel CS, Gundlach AL, Bathgate RA, Separovic F, Wade JD (2012) Minimization of human relaxin-3 leading to high-affinity analogues with increased selectivity for relaxin-family peptide 3 receptor (RXFP3) over RXFP1. J Med Chem 55:1671-1681

Shabanpoor F, Separovic F, Wade JD (2011) General method for selective labelling of double-chain cysteinerich peptides with a lanthanide chelate via solid-phase synthesis. J Pept Sci 17:169-173

Sherwood OD (2004) Relaxin's physiological roles and other diverse actions. Endocr Rev 25:205-234

Smith CM, Hosken IT, Sutton SW, Lawrence AJ, Gundlach AL (2012) Relaxin-3 null mutation mice display a circadian hypoactivity phenotype. Genes Brain Behav 11:94-104

Smith CM, Ryan PJ, Hosken IT, Ma S, Gundlach AL (2011) Relaxin-3 systems in the brain-The first 10 years. J Chem Neuroanat 42:262-275

Smith CM, Shen PJ, Banerjee A, Bonaventure P, Ma S, Bathgate RA, Sutton SW, Gundlach AL (2010) Distribution of relaxin-3 and RXFP3 within arousal, stress, affective, and cognitive circuits of mouse brain. J Comp Neurol 518:4016-4045

Sudo S, Kumagai J, Nishi S, Layfield S, Ferraro T, Bathgate RA, Hsueh AJ (2003) H3 relaxin is a specific ligand for LGR7 and activates the receptor by interacting with both the ectodomain and the exoloop 2. J Biol Chem 278:7855-7862

Sunn N, Egli M, Burazin TC, Burns P, Colvill L, Davern P, Denton DA, Oldfield BJ, Weisinger RS, Rauch M, Schmid HA, McKinley MJ (2002) Circulating relaxin acts on subfornical organ neurons to stimulate water drinking in the rat. Proc Natl Acad Sci U S A 99:1701-1706

Sutton SW, Shelton J, Smith CM, Williams J, Yun S, Motley T, Kuei C, Bonaventure P, Gundlach AL, Liu C, Lovenberg TW (2009) Metabolic and neuroendocrine responses to RXFP3 modulation in the central nervous system. Ann N Y Acad Sci 1160:242-249

Tanaka M, Iijima N, Miyamoto Y, Fukusumi S, Itoh Y, Ozawa H, Ibata Y (2005) Neurons expressing relaxin 3/INSL 7 in the nucleus incertus respond to stress. Eur J Neurosci 21:1659-1670

Wade JD, Lin F, Hossain MA, Dawson RM (2012) Chemical synthesis and biological evaluation of a peptide gonococcal growth inhibitor. Amino Acids 43:2279-2283 
Watanabe Y, Miyamoto Y, Matsuda T, Tanaka M (2010) Relaxin-3/INSL7 Regulates the Stress-response System in the Rat Hypothalamus. J Mol Neurosci 43:169-174

Werle M, Bernkop-Schnurch A (2010) Strategies to improve plasma half life time of peptide and protein drugs. Amino Acids 30:351-367

Wilkinson TN, Speed TP, Tregear GW, Bathgate RAD (2005) Evolution of the relaxin-like peptide family. BMC Evol Biol 5:14 


\section{Figure Legends}

Figure 1. A. Primary structure B. RP-HPLC trace and C. MALDI-TOF MS trace of rat relaxin-3 which is $100 \%$ identical to mouse relaxin-3.

Figure 2. Circular dichroism spectra (CD) of rat/mouse relaxin-3 compared to human relaxin-3 (H3 relaxin). $\mathrm{CD}$ was performed in $10 \mathrm{mM}$ phosphate buffer at $\mathrm{pH}$ 7.5.

Figure 3. Activity of rat/mouse relaxin-3 at RXFP3. A. Competition binding of rat/mouse relaxin-3 or $\mathrm{H} 3$ relaxin with europium labeled R3/I5 in membranes from CHO-K1 cells stably expressing RXFP3. Data are expressed as percentage of specific binding and are pooled data from at least three experiments performed in triplicate. B. Inhibition of forskolin-stimulated cAMP activity in RXFP3 expressing CHO-K1 cells using a pCRE- $\square$-galactosidase reporter gene system. Data are expressed as percentage of forskolin response and are pooled data from at least three experiments performed in triplicate.

Figure 4. Effect of central (icv) administration of rat/mouse relaxin-3 on $\mathbf{A}$. food and $\mathbf{B}$. water consumption in adult Sprague-Dawley rats during a 60 min post-injection period. Rat/mouse relaxin-3 ( $\mathrm{n}=6$ rats); control $(\mathrm{n}=$ 11 rats). 
Figure 1.

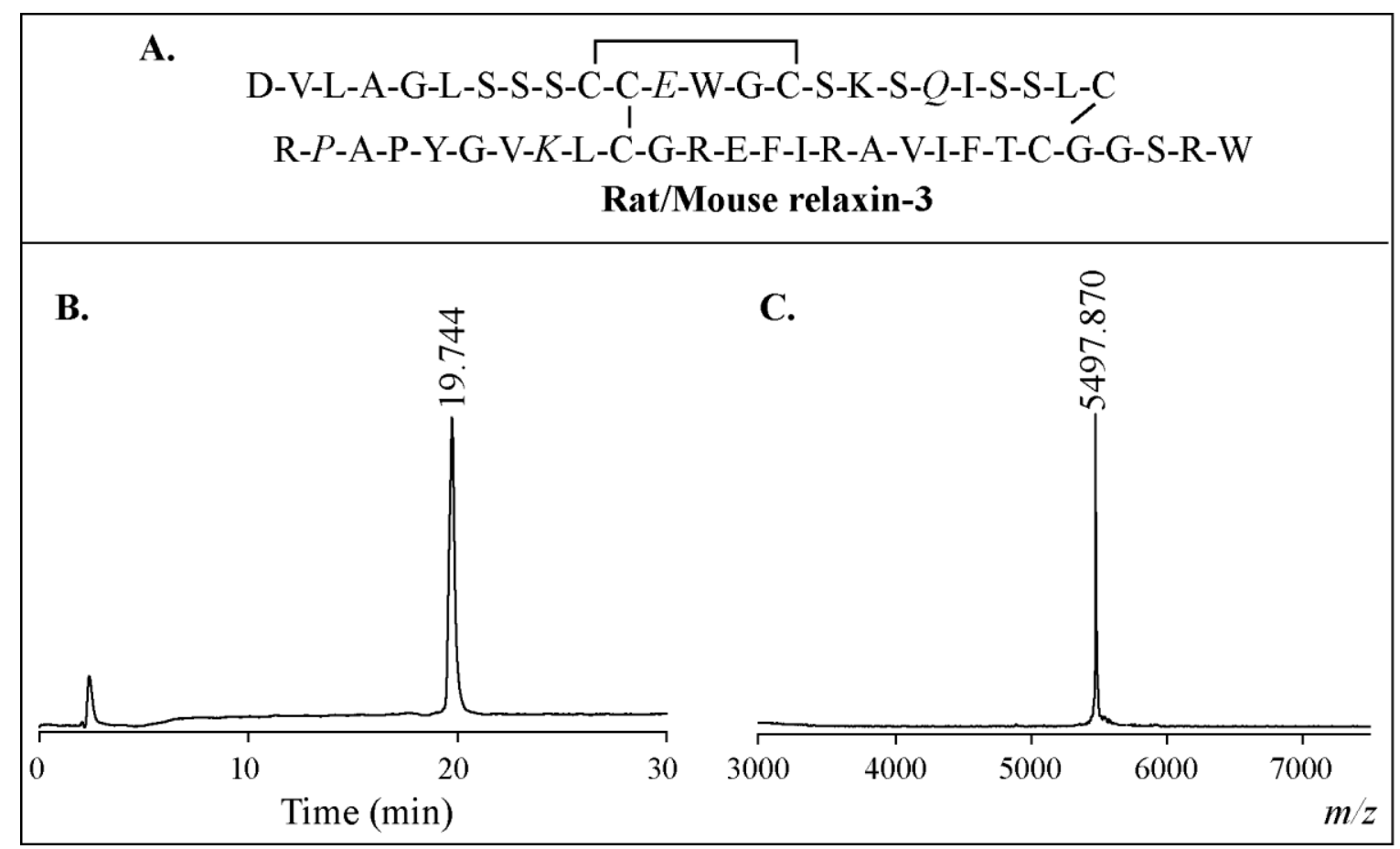


Figure 2.

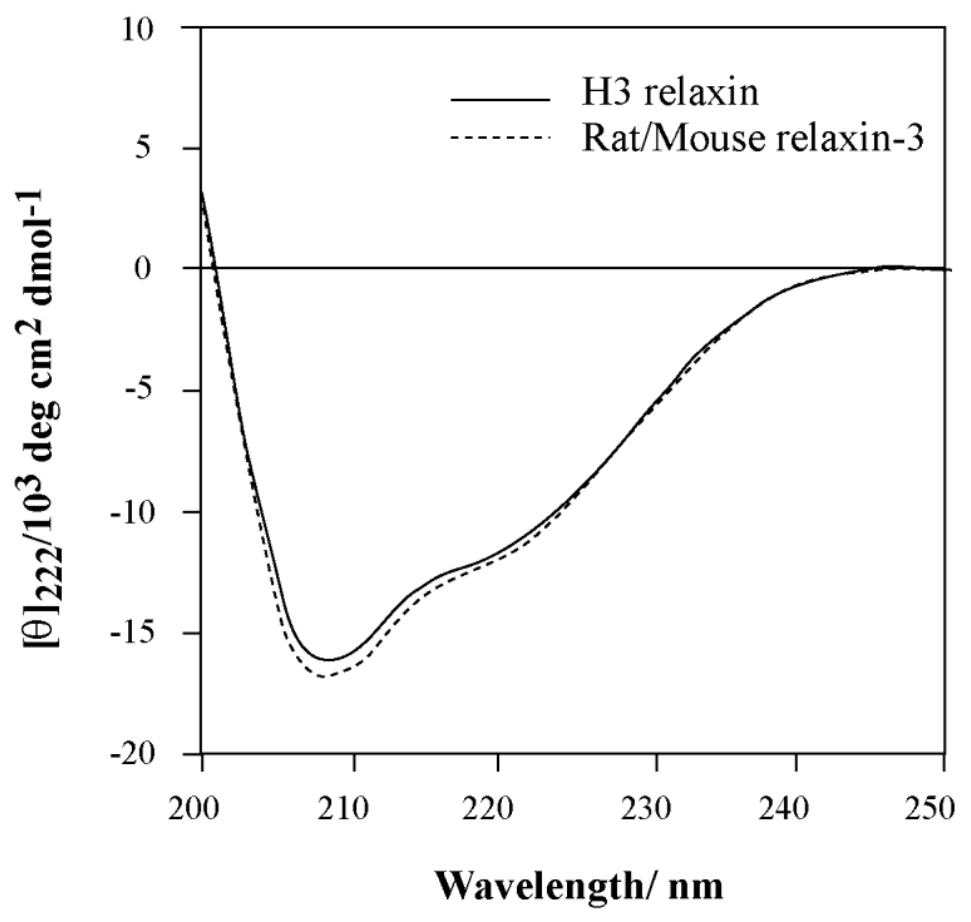


Figure 3.

\section{A. RXFP3 Eu-R3/I5 binding}

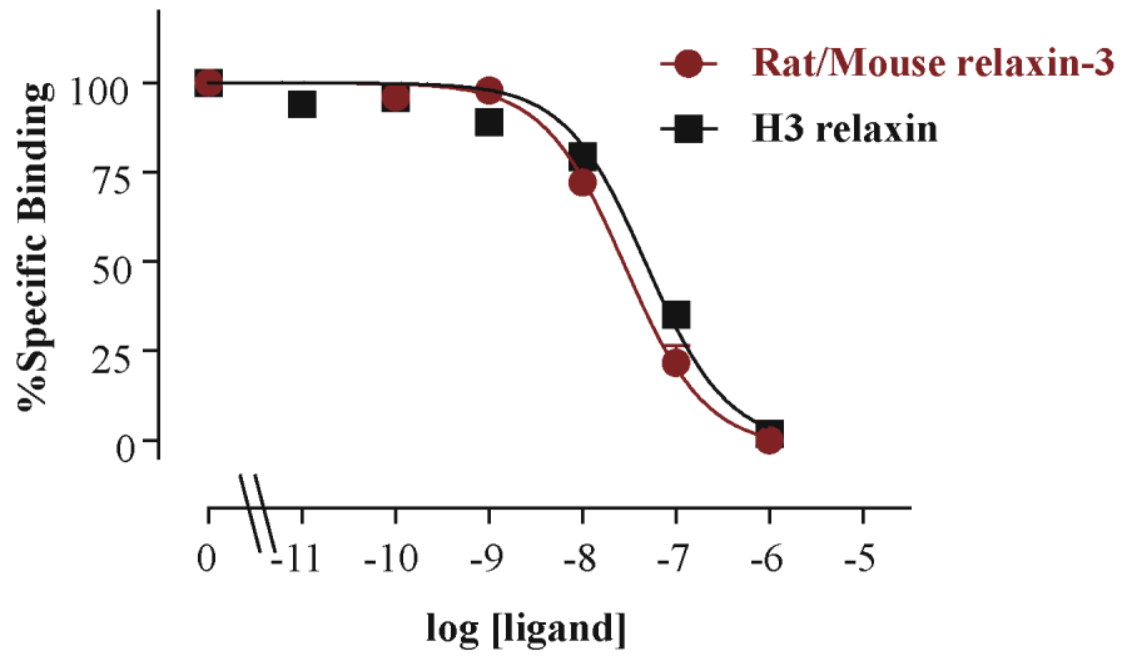

B. RXFP3 cAMP activity

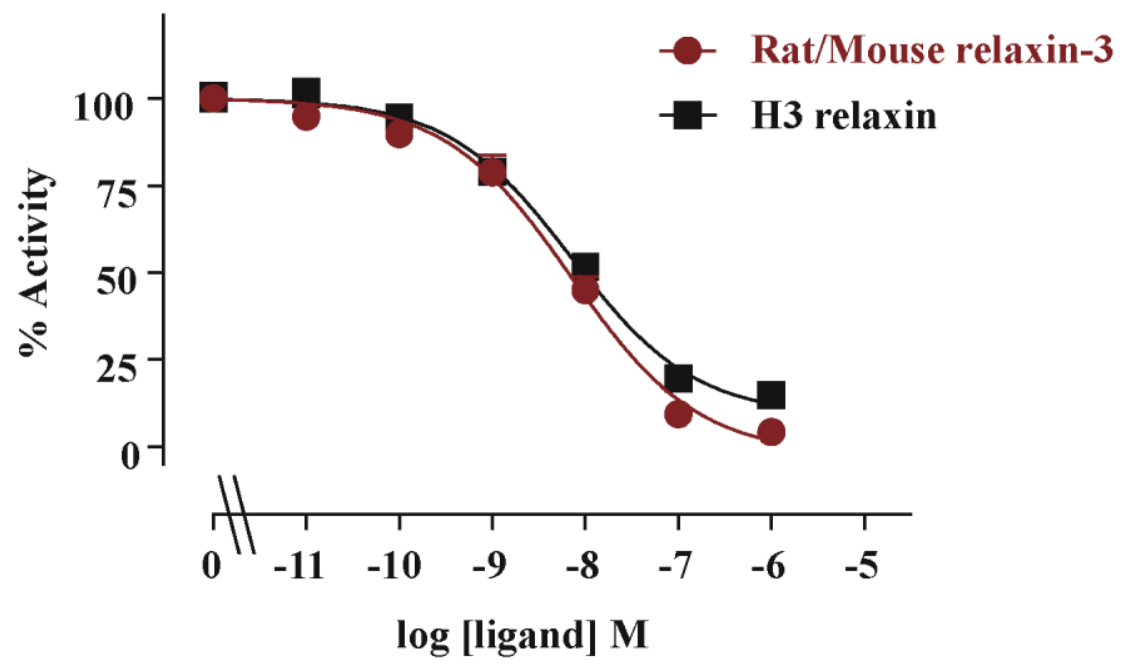


Figure 4.

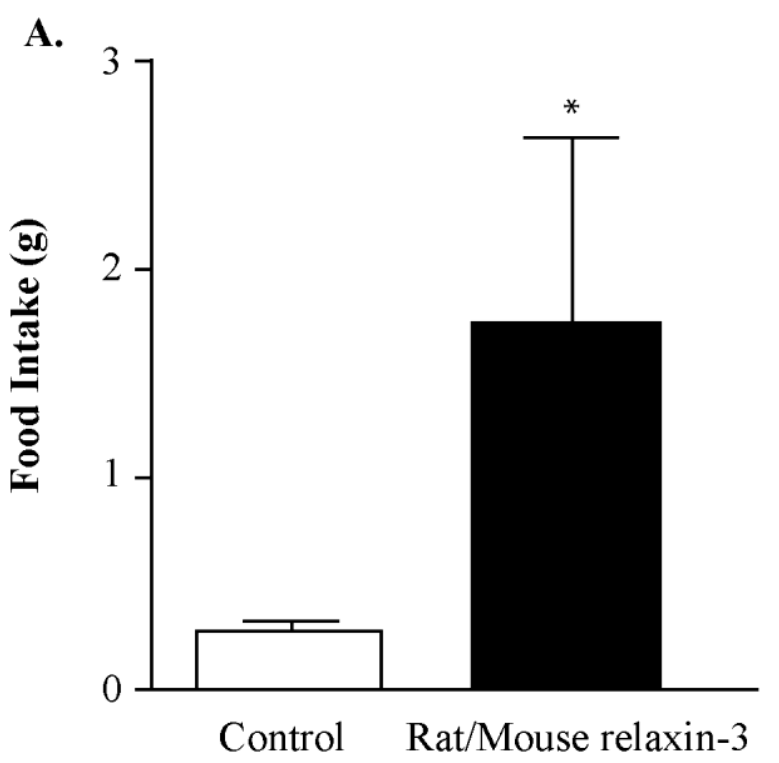

Treatment

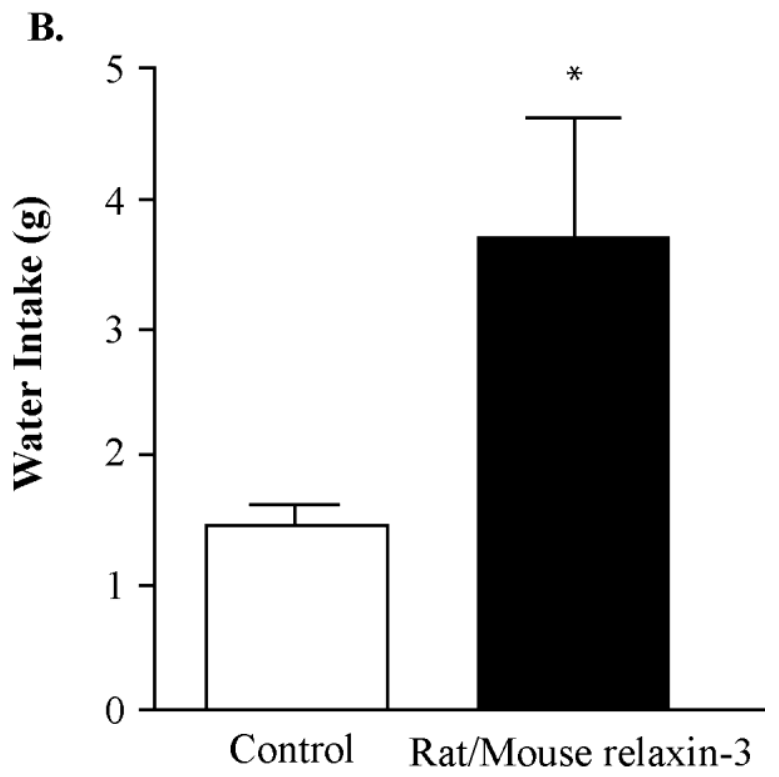

Treatment 